\title{
Identification of $\boldsymbol{N}$-Terminal Methionine in the Precursor of Immunoglobulin Light Chain
}

\author{
INITIATION OF TRANSLATION OF MESSENGER RIBONUCLEIC ACID IN \\ PLANTS AND ANIMALS
}

\author{
By ISRAEL SCHECHTER and YIGAL BURSTEIN \\ Departments of Chemical Immunology and Organic Chemistry, The Weizmann Institute of Science, \\ Rehovot, Israel
}

(Received 1 September 1975)

\begin{abstract}
The proteins programmed in the wheat-germ cell-free system by the mRNA coding for the MOPC-321 mouse myeloma L (light) chain were labelled with ${ }^{35}$ S]methionine, $\left[4,5-{ }^{3} \mathrm{H}\right]$ leucine or $\left[3^{3} \mathrm{H}\right]$ serine, and were subjected to amino acid-sequence analyses. Over $95 \%$ of the total cell-free product was sequenced as one homogeneous protein, which corresponds to the precursor of the L-chain protein. In the precursor, 20 amino acid residues precede the $\mathrm{N}$-terminus of the mature protein. This extra piece contains one methionine residue at the $N$-terminus, one serine residue at position 18 , and six leucine residues, which are clustered in two triplets at positions $6,7,8$ and $11,12,13$. The identification of methionine at the $N$-terminus of the precursor is in agreement with the evidence showing that unblocked methionine is the initiator residue for protein synthesis in eukaryotes. The absence of methionine at position 20 , which precedes the $N$-terminal residue of the mature protein, suggests that myeloma cells synthesize the precursor. However, within the cell the precursor should be rapidly processed to the mature $\mathrm{L}$ chain, since precursor molecules have not yet been found in the intact animal. The abundance $(30 \%)$ of leucine residues indicates that the extra-piece moiety is quite hydrophobic. The extra piece of the MOPC-321 L-chain precursor synthesized with the aid of the Krebs II ascites cell-free system is of identical size and it has the same leucine sequence [Schechter et al. (1975) Science 188, 160-162]. This indicates that cell-free systems derived from the plant and animal kingdom initiate mRNA translation from the same point. It is shown that the amino acid sequence of minute amounts of a highly labelled protein $(0.1 \mathrm{pmol}) \mathrm{can}$ be faithfully determined in the presence of a large excess (over 2000000-fold) of unrelated non-radioactive proteins.
\end{abstract}

Several laboratories have reported that preparations containing the mRNA coding for immunoglobulin L (light) chain direct the synthesis of a precursor, which is larger than the mature $L$ chain (Milstein et al., 1972; Swan et al., 1972; Mach et al., 1973; Tonegawa \& Baldi, 1973; Schmeckpeper et al., 1974; Green et al., 1975). Nonetheless the location and precise size of the extra piece were not determined in these studies. We have shown (Schechter, 1973) that in the Krebs II ascites cell-free system the MOPC-321 L-chain mRNA directs the synthesis of five proteins with mol.wts. of about 28700,25300 , 19700,18200 and 17200 . Despite the fact that none of these proteins is of the same size as the authentic L chain (mol.wt. 24020; see McKean et al., 1973), the tryptic 'fingerprints' that they yield are composed almost entirely of L-chain peptides (Schechter, 1973). The amino acid-sequence analyses of the cell-free products labelled with $\left[4,5-{ }^{3} \mathrm{H}\right]$ leucine showed that all five proteins share an identical pattern of leucine residues. This pattern enabled us to establish that in all five proteins 20 amino acid residues precede the $N$-terminus of the mature MOPC-321 L chain (Schechter, 1973; Schechter et al., 1975). The differences in sizes of the proteins have been attributed to the initiation of mRNA translation at one point with premature termination at several points. However, in the above experiments, the yields from the sequencer runs showed that only a fraction of the labelled material was analysed, and that this fraction varied in the different proteins (yields ranged between 26 and $91 \%$. This could be due to either variable sequencer efficiencies, or to differences in the availability of the $\alpha$-amino groups of the proteins. In other words, we could not rule out the possibility that the samples contained variable amounts of proteins with blocked $\alpha$-amino groups. We now report the results of sequence analyses of MOPC-321 L-chain pre cursors that were synthesized with the aid of the wheat-germ cell-free system and labelled with $\left[{ }^{35}\right.$ S $]$ methionine, $\left[4,5-{ }^{3} \mathrm{H}\right]$ leucine or $\left[3-{ }^{3} \mathrm{H}\right]$ serine. In this system the precursor comprises over $95 \%$ of the 
total cell-free product, and it is sequenced as one homogeneous protein. Data from the $\left[{ }^{35}\right.$ S $]$ methioninelabelled cell-free product indicate that the precursor is synthesized by intact cells. Results from the $\left[{ }^{3} \mathrm{H}\right]$ serine-labelled precursor confirmed the size of the $N$-terminal extra piece that was deduced from the

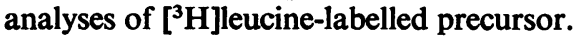

\section{Experimental}

\section{Materials}

The MOPC-321 myeloma tumour (a $\kappa \mathrm{L}$ chain producer), kindly given by Dr. M. Potter (National Institutes of Health, Bethesda, MD, U.S.A.), was maintained as a solid tumour in female BALB/c mice. Commercial wheat germ was supplied by the Bar-Rav Mill, Tel Aviv, Israel. [3- $\left.{ }^{3} \mathrm{H}\right]$ Serine $(15 \mathrm{Ci} / \mathrm{mmol})$, $\left[4,5-{ }^{3} \mathrm{H}\right]$ leucine $(53 \mathrm{Ci} / \mathrm{mmol})$ and $\left[{ }^{35} \mathrm{~S}\right]$ methionine $(250 \mathrm{Ci} / \mathrm{mmol})$ were obtained from The Radiochemical Centre, Amersham, Bucks., U.K. The ten ${ }^{14} \mathrm{C}$-labelled amino acids $(90-320 \mathrm{Ci} / \mathrm{mol})$ were purchased from New England Nuclear, Boston, MA, U.S.A.

\section{Immunoglobulin L-chain mRNA}

The characterization and isolation of the mRNA coding for immunoglobulin L chain from MOPC-321 myeloma polyribosomes, which were specifically precipitated with antibodies to $L$ chain, have been described (Schechter, 1973, 1974a).

\section{Cell-free synthesis of $L$-chain precursors}

Translation of the L-chain mRNA was carried out in the preincubated wheat-germ cell-free system (Roberts \& Paterson, 1973) containing $25 \mathrm{~mm}-\mathrm{KCl}$, $56 \mathrm{~mm}$-potassium acetate and $3.3 \mathrm{~mm}$-magnesium acetate. The reaction mixture contained one of the following: $4.5 \mu \mathrm{M}-\left[{ }^{3} \mathrm{H}\right]$ serine; $2.9 \mu \mathrm{M}-\left[{ }^{3} \mathrm{H}\right]$ leucine; $0.8 \mu \mathrm{M}-\left[{ }^{35} S\right]$ methionine; a mixture of ten ${ }^{14} \mathrm{C}$-labelled amino acids (alanine, arginine, glycine, isoleucine, leucine, lysine, proline, serine, threonine, valine; each at $2.7 \mu \mathrm{M}$ ). Also present were the other 19 or 10 unlabelled amino acids as appropriate (each at $30 \mu \mathrm{M})$. A standard reaction mixture $(40 \mu \mathrm{l})$ contained $0.007 E_{260}$ unit of the MOPC-321 L-chain mRNA. Incubation was at $25^{\circ} \mathrm{C}$ for $4 \mathrm{~h}$. Radioactive material precipitated with $10 \%(w / v)$ trichloroacetic acid was collected on Millipore filters. The dried filters were transferred to $10 \mathrm{ml}$ of toluene containing $0.4 \%$ 2,5-diphenyloxazole and $0.005 \%$ 1,4-bis-(5-phenyloxazol-2-yl)benzene. The radioactivity was determined in a Packard model 3330 liquid-scintillation spectrometer with counting efficiency of $25 \%$ for ${ }^{3} \mathrm{H}$ and $60 \%$ for ${ }^{35} \mathrm{~S}$.

\section{Cell-free product identification}

The molecular weights of the proteins programmed by the mRNA were determined from electrophoretic mobility on sodium dodecyl sulphate/polyacrylamide gels (Maizel, 1972); two-dimensional 'fingerprints' of their tryptic digest were obtained as described by Schechter (1973).

\section{Amino acid sequence analysis}

Cell-free products labelled with $\left[{ }^{3} \mathrm{H}\right]$ serine, $\left[{ }^{3} \mathrm{H}\right]-$ leucine or ${ }^{[35}$ S $]$ methionine were analysed. To the total reaction mixture $(80-120 \mu$ l) were added serine, leucine or methionine (depending on the label used) to a final concentration of $4 \mathrm{mM}, 1 \mathrm{vol}$. of $1 \mathrm{M}$-Tris base, and after $30 \mathrm{~min}$ at $36^{\circ} \mathrm{C} 5 \mathrm{ml}$ of $10 \%(\mathrm{w} / \mathrm{v})$ trichloroacetic acid. The mixture was kept in an ice/water bath for $30 \mathrm{~min}$ and then centrifuged $(2500 \mathrm{~g} / 15 \mathrm{~min})$. The precipitate was washed twice with cold $5 \%(w / v)$ trichloroacetic acid $(6 \mathrm{ml})$, twice with acetone/water $(19: 1, \mathrm{v} / \mathrm{v} ; 7 \mathrm{ml})$; it was then dissolved in $33 \%(\mathrm{v} / \mathrm{v})$ acetic acid and stored at $-80^{\circ} \mathrm{C}$ (up to a period of 3 months) until analysed. The loss of labelled proteins during the washing steps was 5-20\%.

The samples in $33 \%$ acetic acid were supplemented with $5 \mathrm{mg}$ of sperm-whale apomyoglobin and analysed in the Beckman model 890C Automatic Sequencer by a modification (Hermodson et al., 1972) of the method of Edman \& Begg (1967). The anilinothiazolinones from each cycle of the sequencer degradations were dried by a stream of $\mathrm{N}_{2}$ to remove the butyl chloride. The dried material was dissolved in $0.5 \mathrm{ml}$ of ethyl acetate, $8 \mathrm{ml}$ of Bray's (1960) solution was added, and radioactivity was counted in a Packard liquid-scintillation spectrometer. In every run portions $(20 \%)$ of some of the thiazolinones were converted into the corresponding phenylthiohydantoin-amino acids (Edman \& Begg, 1967) and quantified by g.l.c. (Pisano et al., 1972). From these data the repetitive yield (degradation yield in the individual cycle; Edman \& Begg, 1967) and the chemical yields of the apomyoglobin carrier were determined. Repetitive yields of the protein carrier and of the labelled materials ranged between 91 and $94 \%$. All samples were sequenced twice. The pattern of radioactive peaks in the duplicate was identical, and the absolute yields varied at most by $10 \%$.

\section{Results}

Protein synthesis directed by MOPC-321 L-chain mRNA

The mRNA stimulates protein synthesis in the wheat-germ cell-free system (Table 1). Gel electrophoresis (Plate 1) shows that two proteins were programmed, neither of which is of the same size as 


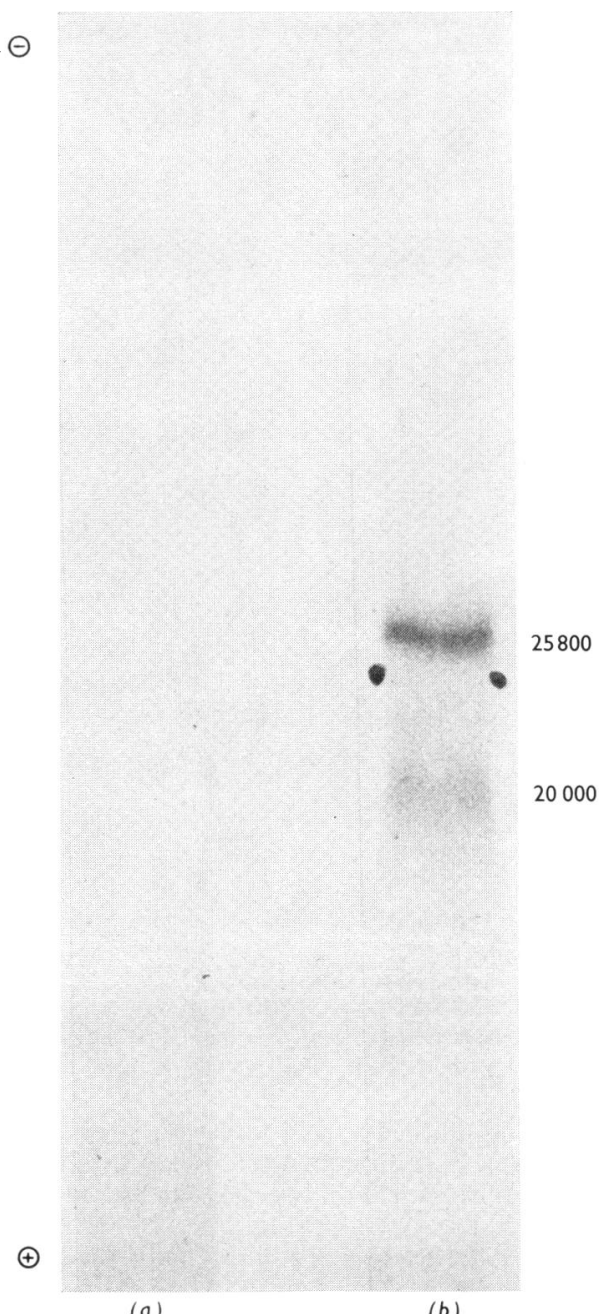

(a)

(b)

\section{EXPLANATION OF PLATE I}

Radioautogram of sodium dodecyl sulphate/polyacrylamide gel of cell-free products programmed by MOPC-321 mRNA in the wheat-germ cell-free system

Total reaction mixtures labelled with ten ${ }^{14} \mathrm{C}$-labelled amino acids were reduced and analysed on slab gels [13\% (w/v) acrylamide, $16 \mathrm{~V} / \mathrm{cm}, 1.5 \mathrm{~h}$ ] as described by Maizel (1972). Results from reaction without $(a)$ and with $(b)$ added mRNA are given. Dots indicate the position of mature MOPC-321 L chain applied with the cell-free sample. Molecular-weight standards were ovalbumin (43000), glyceraldehyde phosphate dehydrogenase (36000), MOPC-321 L chain (24020), myoglobin (17200) and haemoglobin (15500). 


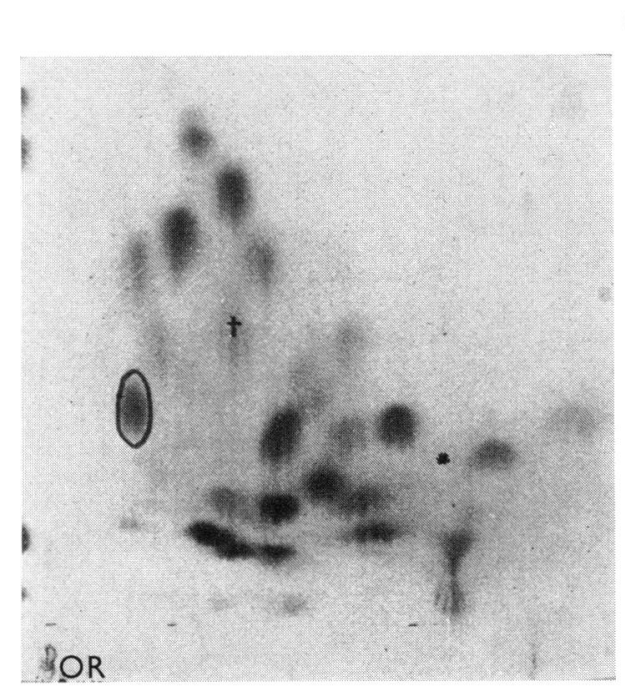

(a)

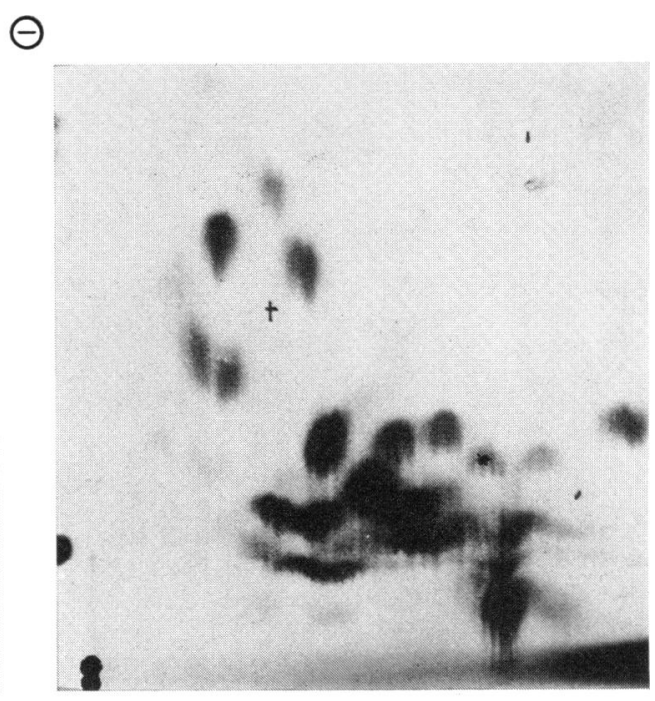

† (b)

\section{EXPLANATION OF PLATE 2}

'Fingerpwints' of authentic MOPC-321 L chain (a) and of cell-free products (b) programmed by MOPC-321 L-chain mRNA in the wheat-germ cell-free system

Total reaction mixtures labelled with ten ${ }^{14} \mathrm{C}$-labelled amino acids were supplemented with $3 \mathrm{mg}$ of MOPC-321 L chain reduced and aminoethylated (Raftery \& Cole, 1963), digested with 'tosylphenylalanine chloromethyl ketone'-treated trypsin (enzyme: substrate ratio of 1:65), loaded on Whatman $3 \mathrm{MM}$ paper $(57 \mathrm{~cm} \times 46 \mathrm{~cm}$ ), and subjected to chromatography (butan1-ol/acetic acid/pyridine/water, 15:3:10:12, by vol.; $14.5 \mathrm{~h}$ ) followed by electrophoresis at $\mathrm{pH} 3.5$ (pyridine/acetic acid water, 1:10:189, by vol.; $3000 \mathrm{~V}, 55 \mathrm{~min}$ ). After exposure to X-ray film the paper was stained with ninhydrin. Only one tryptic peptide, encircled by a continuous line in the stained paper $(a)$, is missing from the radioautogram $(b)$. Several spots are not clearly seen here, but were evident in the original X-ray film and stained paper. For example: $\dagger$ marks a peptide in the stained paper that is hardly seen here in the radioautogram; $\left({ }^{*}\right)$ marks a peptide in the radioautogram that is hardly seen here in the stained paper. Spots in the extreme left represent amino acid markers. OR, origin. 
Table 1. Stimulation of protein synthesis in the wheat-germ cell-free system by the MOPC-321 L-chain $\mathrm{mRNA}$

Reaction mixtures (each of $40 \mu \mathrm{l}$ ) without (control) and with L-chain mRNA $\left(0.007 E_{260}\right.$ unit per reaction) were kept at $25^{\circ} \mathrm{C}$ for $4 \mathrm{~h}$, then the trichloroacetic acid-insoluble radioactivity (c.p.m.) was determined.

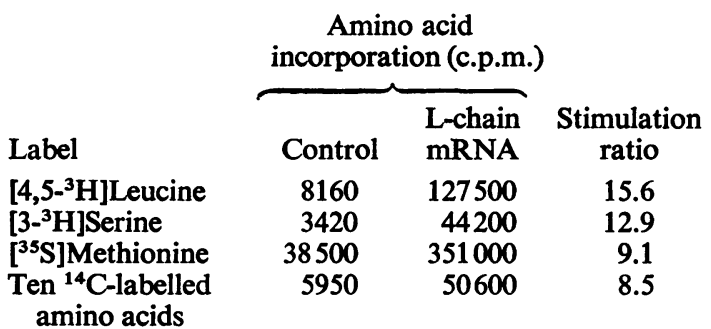

the mature MOPC-321 L chain (mol.wt. 24020). The mol.wt. of the major component is about 25800 , that of the minor component is about 20000. The data quoted below suggest that these proteins represent precursor molecules. Both proteins share an identical $N$-terminus; the smaller protein presumably lacks a portion of the $C$-terminus owing to premature termination of mRNA translation (see the Discussion section). The 'fingerprints' of tryptic digests of the total cell-free product and of the authentic $L$ chain are essentially the same (Plate 2), thus showing that the mRNA is translated with fidelity. All peptides derived from the cell-free product match with authentic peptides. Only one peptide derived from the authentic $L$ chain is missing from the digest of the cell-free product. The missing peptide probably corresponds to the $N$-terminal peptide of the mature protein, which is modified in the precursor (Schechter, 1973). We could not, however, identify the modified peptide. Possibly it remains at the application point, or it is masked by other radioactive peptides.

\section{Sequence of $\left[{ }^{3} \mathrm{H}\right]$ leucine-labelled precursor}

As a control we subjected to sequence analysis a portion of the wheat-germ cell-free system without added mRNA (10800 c.p.m.; equivalent to 1.5 times the amount in the standard reaction). A constant and low radioactive background was obtained (Fig. 1a) thus showing that with $\left[{ }^{3} \mathrm{H}\right]$ leucine labelling the endogenous activity of the cell-free system is negligible. The radioactivity derived from the labelled material is even lower than that observed in Fig. 1(a). This is because the counts measured from sequencer runs of the apomyoglobin carrier alone yielded a constant background of $45 \pm 10$ c.p.m. There was no quenching of $\left[{ }^{3} \mathrm{H}\right]$ serine, $\left[{ }^{3} \mathrm{H}\right]$ leucine, $\left[{ }^{14} \mathrm{C}\right]-$ leucine or $\left[{ }^{35}\right.$ S $]$ methionine added to Bray's (1960) solutions containing thiazolinones obtained from sequencer runs.

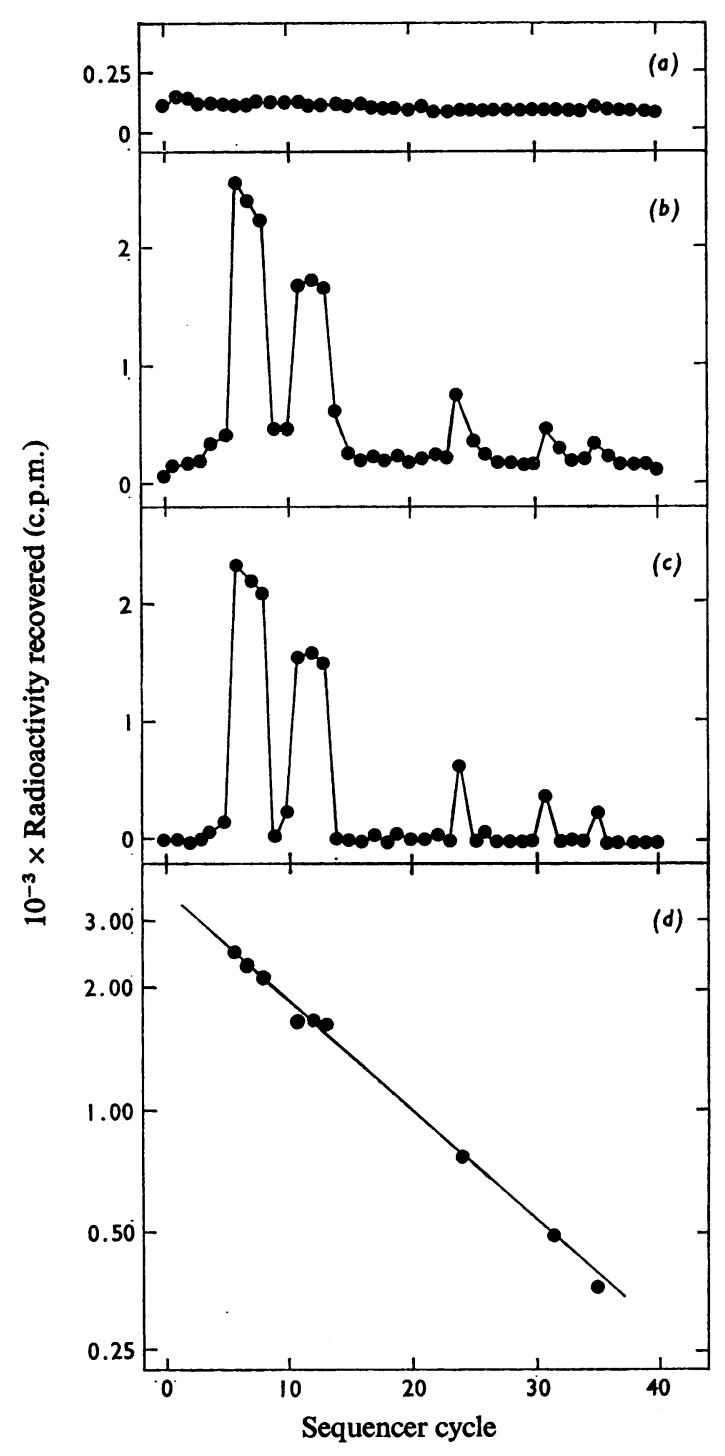

Fig. 1. Radioactivity recovered at each sequencer cycle from cell-free products labelled with $\left[{ }^{3} \mathrm{H}\right]$ leucine without (a) and with $(b, c, d)$ added MOPC-321 $m R N A$

The sample without added mRNA is equivalent to 1.5 times the amount in the standard reaction; it contains 10800 c.p.m. and $5 \mathrm{mg}$ of apomyoglobin. The sample with added MOPC-321 mRNA is equivalent to 0.55 times the amount in the standard reaction; it contains 65000 c.p.m. (0.1 pmol of precursor) and $5 \mathrm{mg}$ of apomyoglobin. (a) Radioactivity recovered at each sequencer cycle from sample without added mRNA. (b) Radioactivity recovered at each sequencer cycle from sample with added mRNA. (c) Data of (b) after correction for background and out-of-step degradation. (d) Semi-log plot of corrected data. Cycle zero represents a blank cycle (without phenyl isothiocyanate), which was used to wash out potential radioactive contaminants. 
Table 2. Recoveries of labelled amino acids obtained from sequencer runs of the MOPC-321 L-chain precursor

The proteins programmed by the MOPC-321 L-chain mRNA in the wheat-germ cell-free system were labelled with different radioactive amino acids. The total reaction mixture was analysed in the Beckman model $890 \mathrm{C}$ Automatic Sequencer, as described in the text. The amount ( $\mathrm{pmol}$ ) of precursor analysed was calculated from the specific radioactivity of the labelling amino acid, counter efficiency, number of amino acid residues in the precursor molecule and from the amount of radioactivity (c.p.m.) in the sample analysed. Chemical yield refers to the apomyoglobin carrier.

\begin{tabular}{|c|c|c|c|c|c|c|c|c|c|}
\hline \multirow[b]{3}{*}{ Label } & \multirow{2}{*}{\multicolumn{2}{|c|}{$\begin{array}{l}\text { Amount of } \\
\text { precursor } \\
\text { analysed }\end{array}$}} & \multicolumn{4}{|c|}{ Calculated radioactivity (c.p.m./residue) } & \multirow{2}{*}{\multicolumn{2}{|c|}{$\begin{array}{c}\text { Radioactive yield } \\
(\%)\end{array}$}} & \multirow{3}{*}{$\begin{array}{c}\text { Chemical } \\
\text { yield } \\
(\%)\end{array}$} \\
\hline & & & \multicolumn{2}{|c|}{ Input } & \multicolumn{2}{|c|}{ Sequencer run } & & & \\
\hline & (pmol) & (c.p.m.) & Uncorrected* & Corrected $†$ & † Observedf & Correcteds & Uncorrected & Corrected & \\
\hline $\begin{array}{l}{\left[4,5-{ }^{3} \mathrm{H}\right] \text { Leucine }} \\
{\left[3-{ }^{3} \mathrm{H}\right] \text { Serine }} \\
{\left[{ }^{35} \mathrm{~S}\right] \text { Methionine }}\end{array}$ & $\begin{array}{l}0.10 \\
0.17 \\
0.08\end{array}$ & $\begin{array}{l}65000 \\
42000 \\
53900\end{array}$ & $\begin{array}{r}3420 \\
1350 \\
17900\end{array}$ & $\begin{array}{r}3200 \\
1250 \\
16000\end{array}$ & $\begin{array}{r}3300 \\
1320 \\
15300\end{array}$ & 14630 & $\begin{array}{l}97 \\
98 \\
86\end{array}$ & $\begin{array}{r}103 \\
105 \\
92\end{array}$ & $\begin{array}{l}94 \\
94 \\
93\end{array}$ \\
\hline
\end{tabular}

The pattern of radioactivity obtained from the $\left[{ }^{3} \mathrm{H}\right]$ leucine-labelled cell-free product $(65000$ c.p.m.; equivalent to 0.55 times the amount in the standard reaction) programmed by the L-chain mRNA (Fig. 1b) is different from that expected for the mature $\mathrm{L}$ chain. The mature MOPC-321 L chain contains leucine residues at positions $4,11,15,50$ etc. (McKean et al., 1973). Radioactive peaks occur at cycles $6,7,8,11,12,13,24,31$ and 35 . However, the leucine residues at positions 24,31 and 35 in the cellfree product match with leucine- $4,-11$ and -15 in the mature protein. Thus we tentatively conclude that the MOPC-321 L-chain mRNA directs the synthesis of a precursor in which 20 amino acid residues are coupled to the $N$-terminus of the mature protein. The $N$-terminal extra piece contains six leucine residues at positions $6,7,8,11,12$ and 13 . The entire precursor molecule contains 19 leucine residues, since the mature protein contains 13 (McKean et al., 1973).

To determine the yields, the crude data (Fig. 1b) were replotted (Fig. 1c) after correction for the background and out-of-step (carry-over from the previous sequencer cycle) radioactivity as described by Smithies et al. (1971). In a semi-log plot all the radioactive peaks were on a straight line, indicating that one protein species was sequenced (Smithies et al., 1971). By extrapolation to cycle 1 it was found that the radioactivity recovered is 3300 c.p.m./leucine residue (Fig. 1d). There are two ways to calculate the expected radioactivity per leucine residue. A value of 3420 c.p.m./leucine residue is obtained by dividing the input $(65000$ c.p.m.) by the number of leucine residues (19) in one precursor molecule. However, the input of radioactivity is the sum of radioactivity derived from stimulation by the added mRNA and radioactivity derived from the endogenous activity of the cell-free system. From the stimulation ratio (Table 1) we estimate that, to a first approximation, the mRNA-dependent counts are $60800(65000 \times$ 14.6/15.6). Therefore the expected value, corrected for endogenous activity, is $3200 \mathrm{c}$.p.m./leucine residue $(60800 / 19)$. In either case, by using the uncorrected or the corrected expected values, the yield obtained is over $97 \%$ (Table 2). That is, the precursor that is sequenced as a homogeneous protein (Fig. 1d) comprises over $97 \%$ of the total cell-free product.

\section{Sequence of $\left[{ }^{3} \mathrm{H}\right]$ serine-labelled precursor}

In order to ascertain the size of the $N$-terminal extra piece detected from $\left[{ }^{3} \mathrm{H}\right]$ leucine labelling, we sequenced precursor molecules containing another labelled amino acid. We chose serine, since it is located in the mature $L$ chain at positions $7,10,14,22$ etc. (McKean et al., 1973). If the extra piece is composed of 20 amino acid residues, we expect to obtain radioactive peaks at cycles 27,30 and 34 from sequence runs of $\left[{ }^{3} \mathrm{H}\right]$ serine-labelled precursor.

As a control we subjected to sequence analysis a portion of the wheat-germ cell-free system without added mRNA (9300c.p.m.; equivalent to 3.3 times the amount in the standard reaction). A constant and low radioactive background was obtained (Fig. 2a), thus showing that with $\left[{ }^{3} \mathrm{H}\right]$ serine labelling the endogenous activity of the cell-free system is negligible.

The pattern of radioactivity obtained from the $\left[{ }^{3} \mathrm{H}\right]$ serine-labelled cell-free product $(42000$ c.p.m.; equivalent to the amount in the standard reaction) programmed by the L-chain mRNA (Fig. $2 b$ ) is different from that expected for the mature $\mathbf{L}$ chain 


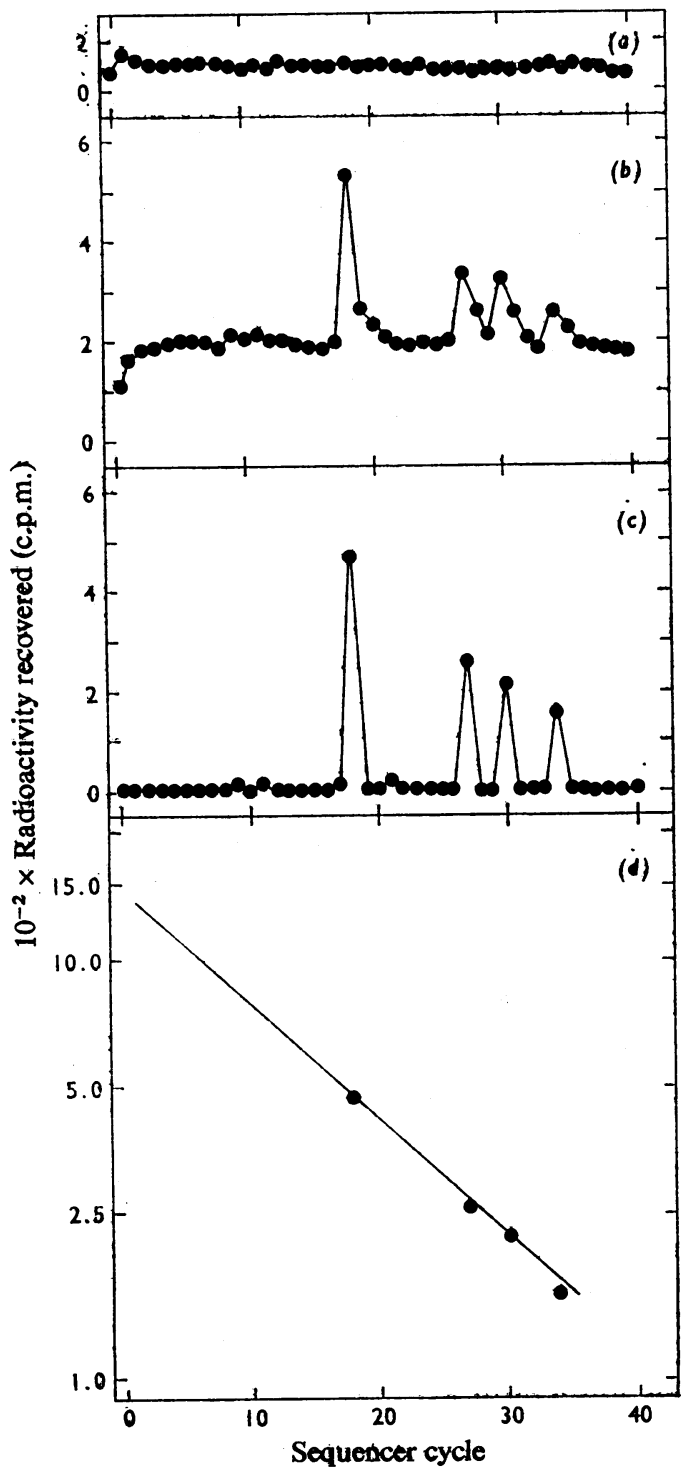

Fig. 2. Radioactivity recovered at each sequencer cycle from cell-free products labelled with $\left[{ }^{3} \mathrm{H}\right]$ serine without (a) and with $(b, c, d)$ added MOPC-321 $m R N A$

The sample without added mRNA is equivalent to 3.3 times the amount in the standard reaction; it contains 9300c.p.m. and $5 \mathrm{mg}$ of apomyoglobin. The sample with added MOPC-321 mRNA is equivalent to the standard reaction mixture; it contains 42000 c.p.m. $(0.17 \mathrm{pmol}$ of precursor) and $5 \mathrm{mg}$ of apomyoglobin. (a) Radioactivity recovered at each sequencer cycle from sample without added mRNA. (b) Radioactivity recovered at each sequencer cycle from sample with added mRNA. (c) Data of (b) after correction for background and out-ofstep degradation. (d) Semt-log plot of corrected data. Cycle zero represents a blank cycle (without phenyl isothiocyanate), which was used to wash out potential radioactive contaminants. (see above). Radioactive peaks occur at positions $18,27,30$ and 34 . The serine residues at positions 27 , 30 and 34 match with serine- $7,-10$ and -14 in the mature protein. These results confirm our conclusion from the leucine sequence data that the $N$-terminal extra piece of the precursor is composed of 20 amino acid residues. The probability of detecting by chance the pattern of leucine and serine residues present in the mature $L$ chain is very low. We have calculated the probability that XXXLXXS XXS L X X S L X X X X X sequence occurs by chance, where $L, S$ and $X$ denote, respectively leucine, serine and amino acid residues other than leucine or serine. If the probability of $L$ and $S$ is $\mathbf{0 . 0 5}$, as it would be if all amino acids occurred at random, the result is $2 \times 10^{-14}$. If the probability of $\mathrm{L}$ is 0.08 and of $\mathrm{S}$ is 0.13 , corresponding to the fraction of leucine and serine in the precursors analysed, the result is $1.5 \times$ $10^{-12}$. The $N$-terminal extra piece contains one serine residue at position 18. The entire precursor molecule contains 31 serine residues, since the mature $L$ chain contains 30 serine residues (McKean et al., 1973).

To determine the yields, the crude data (Fig. $2 b$ ) were processed for background and out-of-step radioactivity (Fig. 2c). The corrected data were plotted semi-logarithmically, and by extrapolation to cycle 1 it was found that the radioactivity recovered is 1320 c.p.m./serine residue (Fig. $2 d$ ). The expected radioactivity per serine residue was calculated as for leucine. The uncorrected value is 1350 c.p.m./serine residue $(42000 / 31)$. When the endogenous activity is considered the radioactivity derived from stimulation by the mRNA is 38800 c.p.m. $(42000 \times 11.9 / 12.9)$, i.e. the corrected expected value is 1250 c.p.m./serine residue $(38800 / 31)$. By using these expected values and the radioactivity recovered in cycle 1 , we calculate that the radioactive yield is: uncorrected, $98 \%$ (1320/1350); corrected, $105 \%(1320 / 1250)$.

\section{Sequence of $\left[{ }^{35}\right.$ S] methionine-labelled precursor}

As unblocked methionine is the initiator residue for protein synthesis in eukaryotes (Chatterjee et al. 1972), we sequenced the $\left[{ }^{35} \mathrm{~S}\right]$ methionine-labelled precursor. As a control we subjected to sequence analysis a portion of the wheat-germ cell-free system without added mRNA (4700c.p.m.; equivalent to 0.27 times the amount in the standard reaction). In contrast with the $\left[{ }^{3} \mathrm{H}\right] l$ leucine- and $\left[{ }^{3} \mathrm{H}\right]$ serine-labelled controls (Figs. $1 a$ and $2 a$ ) the $\left[{ }^{35}\right.$ S] methionine-labelled control showed a distinct peak of radioactivity (670c.p.m.; $14.2 \%$ of the input radioactivity) in cycle 1 , followed by a constant low background up to cycle 41 . The same result was obtained when 5 -fold more material was analysed, i.e. $13.9 \%$ of the input radioactivity was recovered in cycle 1 .

When a sample containing mRNA was analysed (53900c.p.m.; equivalent to 0.27 times the amount in 
the standard reaction), a large peak of radioactivity was observed in cycle 1 (15300c.p.m.), followed by a constant low background up to cycle 43 . Thus the extra piece of the precursor contains one methionine residue at the $N$-terminus. The entire precursor molecule contains three methionine residues, since the mature protein contains two. The absence of methionine in positions $21-43$, which correspond to positions 1-23 in the mature protein, is in agreement with the amino acid sequence of the mature $L$ chain (first methionine is at position 37; McKean et al., 1973).

The corrected radioactivity derived from methionine-1 of the precursor is 14630 c.p.m. (15300-670), since 670 c.p.m. are recovered in cycle 1 from the same amount of cell-free product without added mRNA. The expected radioactivity per methionine residue is calculated in two ways. The uncorrected value is 17900 c.p.m./methionine residue $(53900 / 3)$. When the endogenous activity is considered, the radioactivity derived from stimulation by the mRNA is 48000 c.p.m. $(53900 \times 8.1 / 9.1)$, i.e. the corrected expected value is 16000 c.p.m./methionine residue $(48000 / 3)$. By using these results and the values for radioactivity in cycle 1 , we calculate that the radioactivity yield is: uncorrected, $86 \%(15300 / 17900)$; corrected, $92 \%(14630 / 16000)$.

\section{Discussion}

In the wheat-germ cell-free systems the MOPC-321 L-chain mRNA directs the synthesis of a precursor in which 20 amino acid residues are coupled to the $N$-terminus of the mature protein. The extra piece contains one methionine residue at the $N$-terminus, one serine residue at position 18 , and six leucine residues at positions 6, 7, 8, 11, 12 and 13 (Figs. 1 and 2). The same mRNA preparation programmed in the Krebs II ascites cell-free system a precursor in which 20 amino acid residues precede the $N$-terminus of the mature protein; the leucine residues in this extra piece were also located at positions $6,7,8,11,12$ and 13 (Schechter, 1973; Schechter et al., 1975). This supports the notion that the translation mechanism in plants and animals is quite similar (Roberts \& Paterson, 1973). Our sequence data indicate that cell-free systems derived from cells of either kingdom initiate translation from the same site on the mRNA.

The two proteins identified in the reaction mixture (Plate 1) probably represent precursor molecules. The tryptic 'fingerprints' of the total cell-free products and of the authentic $L$ chain are essentially identical (Plate 2). The high yields of $\left[{ }^{3} \mathrm{H}\right]$ leucine, $\left[{ }^{3} \mathrm{H}\right]$ serine and ${ }^{35}$ S]methionine (Table 2 ) suggest that the two proteins share an identical $N$-terminus. Thus the smaller protein could originate from premature termination of mRNA translation. An analogous situation occurs in the Krebs II ascites cell-free system, where short MOPC-321 precursor molecules ranging in size from 19700 to 17200 daltons were isolated, and each of them was found to have an intact $N$ terminal extra piece (Schechter et al., 1975).

The radioactive peaks derived from sequencer runs of $\left[{ }^{3} \mathrm{H}\right]$ leucine- and $\left[{ }^{3} \mathrm{H}\right]$ serine-labelled products lie on a straight line on semi-log plots (Figs. $1 d$ and $2 d$ ), strongly suggesting that they originate from one protein. The high radioactive yields $(\geqslant 95 \%)$ obtained with the $\left[{ }^{3} \mathrm{H}\right]$ leucine-, $\left[{ }^{3} \mathrm{H}\right]$ serine- and $\left[{ }^{35} \mathrm{~S}\right]-$ methionine-labelled precursors are comparable(Table 2 ), as they should be when one protein is being sequenced. From these results we conclude that the biological purity of the MOPC-321 mRNA is over $95 \%$. A similar value of biological purity $(\geqslant 95 \%)$ was calculated from the precipitation of myeloma and non-myeloma polyribosomes each with anti-(L-chain) and anti-(non-L-chain), from the estimation of trace contamination of the pure MOPC321 mRNA by non-L-chain mRNA activities that are present in large abundance in the myeloma cell (Schechter, 1973), as well as from the hybridization kinetics of the mRNA with its complementary DNA (Schechter, 1975). Taken together, these data show that pure mRNA can be isolated from fully functional eukaryotic cells by means of the immunoprecipitation technique (Schechter, 1974a,b).

Many studies suggest that a distinct unblocked methionine-tRNA functions for protein chain initiation in eukaryotes. Free methionine was found at the $N$-terminus of nascent proteins synthesized by intact eukaryotic cells (Jackson \& Hunter, 1970; Wigle \& Dixon, 1970; Chatterjee et al., 1972). Further evidence came from a variety of studies with eukaryotic cell-free systems (for the list of references see Chatterjee et al., 1972), including the wheat-germ cell-free system (Leis \& Keller, 1970). In agreement, methionine (but not leucine or serine; Figs. $1 a$ and $2 a$ ) was found at the $N$-terminus of the newly synthesized wheat-germ proteins. Experiments indicating that methionine is the initiator amino acid for the synthesis of immunoglobulin $L$ chains have been reported. Milstein et al. (1972) have shown that radioactively labelled L-chain precursor is synthesized in reticulocyte lysate containing L-chain mRNA and formyl[ ${ }^{35}$ S $]$ methionyl-tRNA $A_{\mathrm{f}}$ of Escherichia coli as the sole source of label. Prasad \& Peterkofsky (1975) have found $N$-terminal methionine on myeloma proteins precipitated by antibodies to $L$ chain. The amino acid sequence analyses described here prove that methionine is the $N$-terminal residue of the MOPC-321 L-chain precursor. This is probably true for all immunoglobulin $L$ chains, since we found methionine at the $N$-terminus of the precursors of MOPC-63, MOPC-41 and MOPC-104E L chains (Y. Burstein \& I. Schechter, unpublished work).

The possibility that the MOPC-321 precursor is a translational artifact occurring in vitro is unlikely. 
The MOPC-321 precursor was synthesized with wheatgerm (the present work) and Krebs II ascites (Schechter et al., 1975) cell-free systems, which are known to translate with fidelity different mRNA molecules. It could be argued that within the cell initiation of mRNA translation is different, resulting in the direct synthesis of the mature L chain. However, considering the role of methionine in initiation (see above), we would then have expected to find a methionine residue in the precursor molecule at a position just before the $N$-terminal residue of the mature protein. Our sequence data rule out this possibility since the precursor does not contain methionine at position 20 , which precedes the $N$-terminus of the mature protein. Assuming that the precursor is indeed synthesized within the myeloma cell, then the vast majority of these molecules should be processed to the mature protein rather quickly. This is because the mature L chains, but not precursors, were isolated from MOPC-321 (Schechter, 1973) and MOPC-21 (Milstein et al., 1972; Svasti \& Milstein, 1972) myeloma cells.

The $N$-terminal methionine is fully retained in the intact MOPC-321 precursor molecule for at least $4 \mathrm{~h}$ (the incubation time of the cell-free system). On the other hand, the initiator methionine residue of haemoglobin chains is cleaved when the chains attain a length of 15-20 residues (Jackson \& Hunter, 1970), or within a few minutes of being incorporated (Housman et al., 1970). Rapid elimination of the $N$-terminal methionine occurs in nascent protamine chains (Wigle \& Dixon, 1970) and in the newly synthesized proteins of HeLa cells (Chatterjee et al., 1972). The difference in the rate of methionine removal can be explained in many ways. For example, the $N$ terminal methionine of the MOPC-321 precursor may not be the initiator residue; our wheat-germ cell-free system may lack endoplasmic membrane components presumed to convert the precursor into mature $L$ chain (Milstein et al., 1972), etc. It seems that in most proteins the initiator methionine is linked directly to the $N$-terminus of the mature protein. Tripeptides containing $N$-terminal methionine and two further residues of the mature protein were isolated from the nascent chains of haemoglobin (Met-Val-Leu from the $\alpha$-chain and Met-Val-His from the $\beta$-chain; Jackson \& Hunter, 1970) and of protamine (MetPro-Arg; Wigle \& Dixon, 1970). In these cases the maturation process requires only the removal of methionine. On the other hand, the maturation of the MOPC-321 L-chain precursor involves the removal of an oligopeptide 20 amino acid residues in length. This process may require specific enzyme(s) which are not widespread and are preferentially concentrated in myeloma cells where the precursor is synthesized.

The $N$-terminal extra piece of the precursor is coupled to the variable region of the $L$ chain. Pre- liminary results show that in the precursors of MOPC-321, MOPC-41 and MOPC-104E L chains the extra pieces differ from each other in size and sequence (Y. Burstein \& I. Schechter, unpublished work). This indicates that the extra piece is part of the variable region of the $\mathrm{L}$ chain. The clustering of leucine residues in two triplets (positions 6, 7, 8 and $11,12,13)$ as well as their abundance $(30 \%)$ suggest that this extra piece would be quite hydrophobic. Indeed, preliminary data on the sequence of MOPC321 precursor labelled with several ${ }^{3} \mathrm{H}$-labelled amino acids show that about $55 \%$ of the extra piece is composed of hydrophobic residues. The marked hydrophobicity suggests that the role of the extra piece might be to favour interaction of the precursor with the endoplasmic membranes or with the cell surface (or both).

Finally, we wish to comment on the amount of material analysed in these studies. The sample contains a minute amount of labelled material whose sequence is monitored ( $0.1 \mathrm{pmol}$ or $2.6 \mathrm{ng}$ of precursor) and a small amount of proteins of the wheat-germ cell-free system $(20 \mu \mathrm{g})$. The sample cannot be retained in the sequencer cup without the apomyoglobin carrier $(5 \mathrm{mg}, 290 \mathrm{nmol})$, since otherwise it would have been washed away in the coupling/cleaving cycles. One could envisage difficulties in recovering $0.1 \mathrm{pmol}$, which is the maximal amount of labelled amino acid derivative released from the precursor. It could be adsorbed on the carrier, or released gradually depending on the type of amino acid liberated from the protein carrier at any sequencer cycle. The results, however, were that the radioactivity was recovered in discrete peaks at the correct position. In conclusion, these experiments demonstrate that minute amounts $(0.1 \mathrm{pmol})$ of a highly labelled protein can be sequenced faithfully in the presence of a large excess (over 2000000 -fold) of unrelated non-radioactive proteins.

We thank Dr. Edward L. Kuff for discussion of the manuscript and Mrs. Ida Oren for assistance with sequencer analyses.

\section{References}

Bray, G. A. (1960) Anal. Biochem. 1, 279-285

Chatterjee, N. K., Kerwar, S. S. \& Weissbach, H. (1972) Proc. Natl. Acad. Sci. U.S.A. 69, 1375-1379

Edman, P. \& Begg, G. (1967) Eur. J. Biochem. 1, 80-91

Green, M., Graves, P. N., Zehavi-Willner, T., McInnes, J. \& Pestka, S. (1975) Proc. Natl. Acad. Sci. U.S.A. 72, 224-228

Hermodson, M. A., Ericsson, L. H., Titani, K., Neurath, H. \& Walsh, K. A. (1972) Biochemistry 11, 4493-4502

Housman, D., Jacobs-Lorena, M., Rajbhandary, U. L. \& Lodish, H. F. (1970) Nature (London) 227, 913-920

Jackson, R. \& Hunter, T. (1970) Nature (London) 227, 672-676

Vol. 153 
Leis, P. J. \& Keller, E. B. (1970) Biochem. Biophys. Res. Commun. 40, 416-421

Mach, B., Faust, C. \& Vassali, P. (1973) Proc. Natl. Acad. Sci. U.S.A. 70, 451-455

Maizel, J. V. (1972) Methods Virol. 5, 179-246

McKean, D., Potter, M. \& Hood, L. (1973) Biochemistry 12, 749-759

Milstein, C., Brownlee, G. G., Harrison, T. M. \& Mathews, M. B. (1972) Nature (London) New Biol. 239, 117-120

Pisano, J. J., Bronzert, T. J. \& Brewer, H. B. (1972) Anal. Biochem. 45, 43-59

Prasad, C. \& Peterkofsky, A. (1975) J. Biol. Chem. 250, 171-174

Raftery, M. A. \& Cole, R. D. (1963) Biochem. Biophys. Res. Commun. 10, 467-472

Roberts, B. E. \& Paterson, B. M. (1973) Proc. Natl. Acad. Sci. U.S.A. 70, 2330-2334

Schechter, I. (1973) Proc. Natl. Acad. Sci. U.S.A. 70, 2256-2260
Schechter, I. (1974a) Biochemistry 13, 1875-1885

Schechter, I. (1974b) Biochem. Biophys. Res. Commun. $57,857-864$

Schechter, I. (1975) Proc. Natl. Acad. Sci. U.S.A. 72, 2511-2514

Schechter, I., McKean, D., Guyer, R. \& Terry, W. (1975) Science 188, 160-162

Schmeckpeper, B. J., Cory, S. \& Adams, J. M. (1974) Mol. Biol. Reports 1, 355-363

Smithies, O., Gibson, D., Fanning, E. M., Goodfliesh, R. M., Gilman, J. G. \& Ballantyne, D. L. (1971) Biochemistry 10, 4912-4921

Svasti, J. \& Milstein, C. (1972) Biochem. J. 126, 837-850

Swan, D., Aviv, H. \& Leder, P. (1972) Proc. Natl. Acad. Sci. U.S.A. 69, 1967-1971

Tonegawa, S. \& Baldi, I. (1973) Biochem. Biophys. Res. Commun. 51, 81-87

Wigle, D. T. \& Dixon, G. H. (1970) Nature (London) 227, 676-680 